\title{
Cell Wall Composition in Mycobacterium lepraemurium
}

\author{
By C. S. CUMMINS, GLADYS ATFIELD \\ The London Hospital Medical College, London, E. I \\ R. J. W. REES AND R. C. VALENTINE \\ National Institute for Medical Research, London, N.W. 7
}

(Accepted for publication 30 May 1967)

\begin{abstract}
SUMMARY
Cell-wall fractions from Mycobacterium lepraemurium were examined chemically and immunologically. The major sugar and amino acid components detected were arabinose and galactose, alanine, glutamic acid, $\alpha, \epsilon$-diaminopimelic acid (DAP) and hexosamine, but substantial amounts of aspartic acid, glycine, valine, serine, threonine, leucine and iso-leucine were also present in preparations not extracted with neutral lipid solvents and alkaline ethanol. However, after such extraction and treatment with proteolytic enzymes, alanine, glutamic acid and DAP $(\mathrm{I} \cdot 5: \mathrm{I} \cdot 0: \mathrm{I} \cdot 0)$ were present in much larger amounts than any other amino acids (not more than $0 \cdot 15$ ), indicating that these three are the mucopeptide constituents. Cell-wall agglutination tests indicated the presence of an antigen shared with other mycobacteria.
\end{abstract}

\section{INTRODUCTION}

Examination of cell wall fractions prepared from a number of strains of mycobacteria have shown a common pattern of components which these organisms share with strains of nocardia and some corynebacteria (Cummins \& Harris, I958; Cummins I962). This common pattern is characterized by the presence of the sugars arabinose and galactose, and of alanine, glutamic acid and DL-diaminopimelic acid as mucopeptide amino acids. In addition, it has been noted (Cummins, 1962) that organisms whose cell walls show this pattern have a cell-wall antigen in common.

Mycobacterium lepraemurium is the causative organism of a chronic infection in wild rats known as rat leprosy. The organism has not been grown in ordinary bacteriological medium; however, it has been grown in tissue culture (Rees \& Garbutt, 1962). $M$. lepraemurium has a generation time of about Io days in tissue culture and in vivo. Therefore it seemed of interest to examine cell-wall fractions from this very slowly growing and obligate intracellular species of mycobacterium to see whether its cell wall was of the same general type as that of all other mycobacterial species examined.

\section{METHODS}

Preparation of Mycobacterium lepraemurium suspensions. The Douglas strain of $M$. lepraemurium (Balfour-Jones, I937) was used; suspensions of the organism were prepared by homogenizing heavily infected liver from mice injected intravenously 4-6 months previously with $M$. lepraemurium (Rees, Valentine \& Wong, 1960). The liver homogenates were prepared in $0 \cdot 0 \mathrm{I}$ M-phosphate buffer $\left(\mathrm{pH}_{7} \cdot \mathrm{I}\right)$ and partially 
purified suspensions of organisms obtained by repeated centrifugation and washing in buffer.

Electron microscopy. Samples were suitably diluted with distilled water and thin layers allowed to dry on electron microscope specimen supports covered with carbon films. The preparations were shadowed with platinum before examination in the electron microscope.

Preparation of cell walls. This was done either by the method of Cummins \& Harris (I956) (omitting ribonuclease treatment) or by disintegration in a Mickle shaker followed by centrifugation in a sucrose gradient in which the walls formed a layer above $40 \%(\mathrm{w} / \mathrm{v})$ sucrose.

Extraction with neutral solvents. This was done at $37^{\circ}$. The material was first extracted twice with ethanol + ether $(I+I, v / v)$, and then twice with chloroform + methanol $(\mathrm{I}+\mathrm{I}, \mathrm{V} / \mathrm{V})$, the total extraction period being several weeks. During this time the extraction mixtures were shaken occasionally by hand.

Extraction with alkaline ethanol. Absolute ethanol containing $0.5 \% \mathrm{KOH}$ was used, and the extraction was continued for 2-3 days at $37^{\circ}$, with occasional shaking. The mixture was centrifuged, and the extracted, deposited material washed twice with absolute alcohol and then three times with distilled water.

Chromatography. Material was hydrolysed in $6 \mathrm{~N}-\mathrm{HCl}$ for $\mathrm{I} 8 \mathrm{hr}$ at $105^{\circ}$, the liquid filtered and the filtrate evaporated to dryness at $100^{\circ}$ over a water bath. The soluble material was taken up in a small quantity of distilled water. To identify the amino acids two-dimensional ascending chromatograms were run in $10 \mathrm{in}$. squares of Whatman no. I paper. The first solvent was butanol+acetic acid + water $(120+30+50$, by vol.) and the second phenol+ammonia + water (phenol $80+$ water $20, \mathrm{v} / \mathrm{v}$; $+\mathrm{I} \mathrm{ml}$. sp.gr. 0.880 ammonia per $200 \mathrm{ml}$.). The spots were made visible with $0.2 \%$ ninhydrin in $95 \%(\mathrm{v} / \mathrm{v})$ acetone in water.

For the separation of diaminopimelic acid (DAP) isomers descending chromatograms were run using the methanol + pyridine $+\mathrm{HCl}+$ water solvent (Hoare \& Work, 1957).

For sugars the method was that of Cummins \& Harris (1956), except that onedimensional descending chromatograms were used, the solvent being ethyl acetate + pyridine + water $(9+2+2$ by vol. $)$.

Quantitative estimation of amino acids. This was done by the method of Atfield \& Morris (196I) with high-voltage paper electrophoresis. The results were expressed as molar ratios, taking $\mathrm{DAP}=\mathrm{I} \cdot \mathrm{O}$.

Cell-wall agglutination tests. The method was that of Cummins \& Slade (196I) except that an MSE sonic disintegrator was used to redisperse the cell wall fragments.

\section{RESULTS}

Chemical analyses were done on samples of Mycobacterium lepraemurium cell walls prepared in four different ways (see Table I). Quantitative amino acid analyses were made on all four samples, but qualitative examination for amino acids and sugars were also done on sample B, as was the determination of the type of DAP present.

Electron micrographs of the fractions analysed showed them to be very largely composed of cell walls, as can be seen in P1. I, fig. I, which shows a preparation made from sample C. A preparation from sample D was also examined ( $\mathrm{Pl}$. I, fig. 2). The 
cell walls of sample $\mathrm{C}$ were generally almost intact, while in sample $\mathrm{D}$ they were mostly fragmented and showed a greater tendency to aggregate. However, considering that sample $\mathrm{D}$ had been prepared from sample $\mathrm{C}$ by procedures which resulted in an $85 \%$ loss of weight (see Table $\mathrm{I}$ ) there is surprisingly little difference to be noted in the appearance of the cell-wall fragments in the two samples.

Table I. Methods of preparation of Mycobacterium lepraemurium cell-wall fractions

\begin{tabular}{|c|c|}
\hline Sample & Method of preparation \\
\hline A & $\begin{array}{l}\text { Formalin-killed suspension disintegrated, deposit treated with trypsin and pepsin, } \\
\text { extracted with } 0.5 \% \mathrm{KOH} \text { in ethanol for } 24 \mathrm{hr} \text { at } 37^{\circ} \text {; finally washed with ethanol } \\
\text { and distilled water }\end{array}$ \\
\hline B & $\begin{array}{l}\text { Organisms allowed to autolyse for } \mathrm{r} \text { month at } 37^{\circ} \text {, disintegrated, and cell-wall fraction } \\
\text { separated by centrifugation in sucrose gradient }\end{array}$ \\
\hline $\mathrm{C}$ & $\begin{array}{l}\text { Fresh suspension disintegrated, cell walls separated by centrifugation in sucrose } \\
\text { gradient: no other treatment except for washing }\end{array}$ \\
\hline D & $\begin{array}{l}\text { Prepared from part of sample } \mathrm{C} \text { by thorough extraction at } 37^{\circ} \text { with neutral lipid } \\
\text { solvents (ethanol+ether } 4 \text { weeks, chloroform }+ \text { methanol } 6 \text { weeks), followed by } \\
0.5 \% \mathrm{KOH} \text { in ethanol ( } 3 \text { days at } 37^{\circ} \text { ). Finally the residue was washed with abso- } \\
\text { lute ethanol and then distilled water, and treated with trypsin and pepsin. Final } \\
\text { yield }=15 \% \text { : i.e. } 13.4 \mathrm{mg} \text {. of sample C yielded } 2.0 \mathrm{mg} \text {. of sample D. }\end{array}$ \\
\hline
\end{tabular}

Table 2. Qualitative composition of Mycobacterium lepraemurium cell walls; sample $B$

\begin{tabular}{|c|c|c|}
\hline \multicolumn{2}{|c|}{ Amino acids } & Sugars and amino su \\
\hline $\begin{array}{l}\text { Ala } \\
\text { Glu } \\
\text { DAP (DL ar }\end{array}$ & 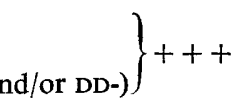 & $\left\{\begin{array}{l}\text { Arabinose }+++ \\
\text { Galactose }++ \\
\text { Mannose trace }\end{array}\right.$ \\
\hline $\left.\begin{array}{l}\text { Asp } \\
\text { Gly } \\
\text { Ser } \\
\text { Threonine } \\
\text { Valine } \\
\text { Leucines }\end{array}\right\}$ & + & Hexosamines + \\
\hline $\left.\begin{array}{l}\text { Lysine } \\
\text { Arginine }\end{array}\right\}$ & trace & \\
\hline
\end{tabular}

Qualitative analyses

The results of chromatography of acid hydrolysates of Mycobacterium lepraemurium cell walls is shown in Table 2 . The principal amino acids found were alanine, glutamic acid and DAP, the latter the DL-isomer (or DL + DD), and the principal sugars identified were arabinose and galactose, with a trace of mannose. This pattern of sugar and amino acid components is that to be expected in a mycobacterium (Cummins \& Harris, 1958; Cummins, 1962). The identity of the hesoxamines is not known for certain, since the chromatographic method used did not separate glucosamine and muramic acid, but it may be assumed that both are present.

Quantitative amino acid analyses

The high-voltage electrophoretic method used enabled analyses to be done on samples of $\mathrm{I}$ mg. or less. The results obtained with samples A-D are recorded in 
Table 3; these results are the mean of two estimations in each case. It is obvious from an examination of these results that the method of preparation of cell-wall fractions has a very considerable influence on the total amino acid content and also on the molar ratios of the different amino acids present, especially the latter. The most interesting comparison is between samples $\mathrm{C}$ and $\mathrm{D}$, since the latter was prepared from the former by a rather extensive extraction with lipid solvents followed by treatment with proteolytic enzymes. This resulted in a very considerable loss of weight: for example, I3.4 mg. of sample C after treatment gave only $2.0 \mathrm{mg}$. of sample D as the final product, a yield of about $15 \%$. It might be expected that such treatment would remove all amino acid-containing material except mucopeptide. The results suggest that this had in fact happened to a large extent, since over $80 \%$ of the total amino acid content of sample $\mathrm{D}$ was made up of alanine, glutamic acid and diaminopimelic acid. In view of this it seems reasonable to suppose that these are the mucopeptide amino acids in Mycobacterium lepraemurium. In the starting material $\mathrm{C}$, however, which had no treatment except separation in a sucrose gradient followed by washing in distilled water, the picture was very different; appreciable amounts of aspartic acid, glycine, leucines, valine and serine, were present, with rather smaller amounts of 7 other amino acids. The pattern is similar in samples A and B, although the amounts of non-mucopeptide amino acids are lower.

Table 3. Mean molar ratios of amino acids in cell-wall fractions prepared from Mycobacterium lepraemurium in different ways

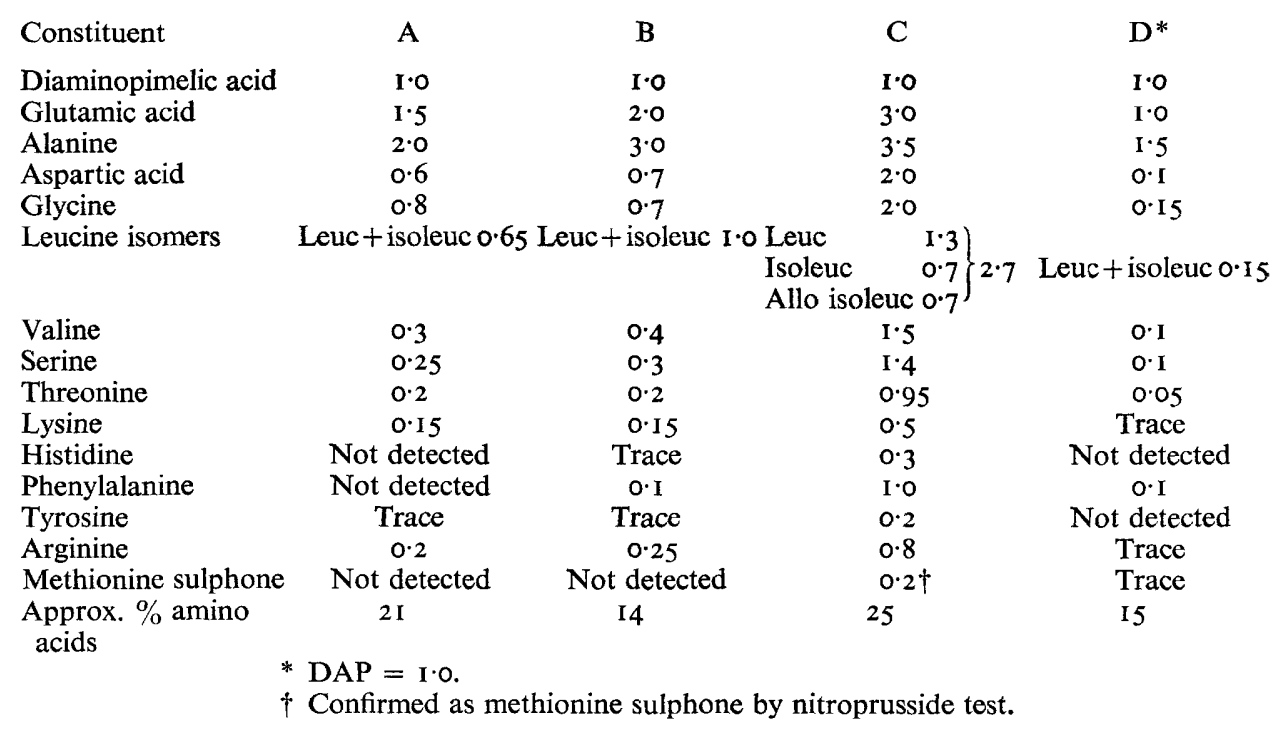

Serological tests with Mycobacterium lepraemurium cell-wall preparations

The results of cell-wall agglutination tests are given in Table 4, and show clearly that Mycobacterium lepraemurium contains a cell-wall antigen shared with other mycobacteria, since suspensions of cell walls prepared from it agglutinated with antismegmatis serum in the same way as cell-wall fractions from the BCG and avian strains of $M$. tuberculosis. In fact, $M$. lepraemurium cell-wall suspensions agglutinated 
to the same titre as those of the avian strain. Antiserum $583 \mathrm{G}$, which had been prepared against $M$. lepraemurium itself, seemed to contain only a little antibody against the common mycobacterial antigen.

Agglutination tests were not possible with many of the samples of cell walls prepared from Mycobacterium lepraemurium suspensions because of auto-agglutination in saline; broadly speaking it was only when the bacteria were extracted with neutral solvents and then with alkaline ethanol that the cell-wall fractions made from them were sufficiently stable in saline to be used in agglutination tests, i.e. samples A and D. Table I. This parallels similar findings for other mycobacteria (see Cummins \& Harris, I958; Cummins, I962). However, during the present work it was noticed that cell-wall suspensions prepared in a sucrose gradient after disintegration of freshly made suspensions of $M$. lepraemurium were stable in saline and gave a titre against $M$. smegmatis antiserum similar to that recorded in Table I for suspension of extracted cell walls.

Table 4. Agglutination tests with cell-wall suspensions from Mycobacterium lepraemurium and some other mycobacteria

\begin{tabular}{|c|c|c|c|c|c|c|c|c|}
\hline Serum & $\begin{array}{c}\text { Cell-wall } \\
\text { suspension } \dagger \text { from }\end{array}$ & 20 & 40 & 80 & 160 & 320 & 640 & SAL \\
\hline \multirow[t]{2}{*}{$\begin{array}{l}\text { Antiserum SMEG } \\
\text { RII } / 62^{2}\end{array}$} & $\begin{array}{l}\text { M. smegmatis* } \\
\text { M. tuberculosis } \mathrm{BCG} \\
\text { M. tuberculosis, }\end{array}$ & $\begin{array}{l}++ \\
++ \\
++\end{array}$ & $\begin{array}{l}++ \\
++ \\
++\end{array}$ & $\begin{array}{l}++ \\
++ \\
++\end{array}$ & $\begin{array}{c}++ \\
++ \\
+\end{array}$ & $\begin{array}{l}+ \\
+ \\
-\end{array}$ & $\begin{array}{l} \pm \\
+ \\
-\end{array}$ & $\begin{array}{l}- \\
- \\
-\end{array}$ \\
\hline & $\begin{array}{l}\text { avian type } \\
\text { M. lepraemurium } \\
\text { (sample D) }\end{array}$ & ++ & ++ & ++ & + & $\operatorname{Tr}$ & - & - \\
\hline $\begin{array}{l}\text { Antiserum } \\
M \text {. lepraemurium } \\
583 \mathrm{G}\end{array}$ & $\begin{array}{l}\text { M. tuberculosis BCG } \\
\text { M. lepraemiruum } \\
\text { (sample D) }\end{array}$ & $\begin{array}{l}+ \\
\pm\end{array}$ & $\stackrel{ \pm}{\mathrm{Tr}}$ & $\begin{array}{l}- \\
-\end{array}$ & $\begin{array}{l}- \\
-\end{array}$ & $\begin{array}{l}- \\
-\end{array}$ & . & $\begin{array}{l}- \\
-\end{array}$ \\
\hline $\begin{array}{l}\text { Normal rabbit } \\
\text { serum }\end{array}$ & $\begin{array}{l}\text { M. lepraemurium } \\
\text { (sample D) }\end{array}$ & - & - & . & . & . & . & - \\
\hline
\end{tabular}

Because of the limited amount of material available it was not possible to do full absorption tests. However, in a single test, I ml. of a I/80 dilution of Mycobacterium smegmatis serum was absorbed with $2 \mathrm{mg}$. of $M$. lepraemurium cell walls. On testing the absorbed samples against $M$. smegmatic cell-wall suspension it appeared that all antibodies had been removed.

\section{DISCUSSION}

These results provide clear evidence that the cell walls of Mycobacterium lepraemurium closely resemble those of other mycobacteria, both chemically and serologically. The presence of arabinose and galactose as principal cell-wall sugars, and of alanine, glutamic acid and DAP as mucopeptide amino acids, coupled with evidence that the walls contain a high proportion of lipid (loss of weight on extraction with neutral lipid solvents) are all typical of this group of organisms. Unfortunately it was not possible to analyse the lipids extracted, as it would have been of interest to know whether or not they contained mycolic acid, and also whether the chloroform-soluble 
fractions had any adjuvant activity of the type described by White, Coons \& Connolly (I955) in Wax D from other mycobacteria.

As mentioned above, the considerable differences in amino acid patterns between samples $\mathrm{C}$ and $\mathrm{D}$ make it clear that alanine, glutamic acid and DL-diaminopimelic acid are the mucopeptide amino acids in this organism. However the rather large number of amino acids in sample $\mathrm{C}$ indicate the presence of other peptide material in the unextracted wall.

If it is assumed that in samples A, B and C a certain amount of alanine and glutamic acid are also 'non-mucopeptide', it appears possible that there is a peptide in these cell-wall samples, not associated with mucopeptide, which is largely composed of glutamic acid, alanine, aspartic acid, glycine, leucines, valine and serine. It seems that thorough treatment with lipid solvents, followed by proteolytic enzymes, is necessary to remove this peptide, which is perhaps associated with lipid; but these treatments were not fully investigated in all combinations. It is interesting to compare these results with those obtained by Belknap, Camien \& Dunn (I96I) for other mycobacteria. These workers examined 4 strains, 2 of Mycobacterium tuberculosis, one of $M$. ranae, and an unclassified 'Battey' strain, and found the major components in each case were alanine, glutamic acid and diaminopimelic acid. They also found appreciable amounts of aspartic acid, glycine, serine, leucines, threonine and valine, although not all of these were present in every strain. The cell-wall material prepared by Belknap et al. was made from organisms which had been extracted rather brieffy with acetone and ether and then dried; after disintegration, the cell-wall fractions were treated with trypsin and pepsin.

Aspartic acid and glycine have also been found as the principal 'non-mucopeptide' amino acids in the peptido-glycolipids of Wax D in avian, bovine and saprophytic strains of mycobacteria (Jollès, Samour \& Lederer, 1963). Misaki, Yukawa, Tsuchiya \& Yamasaki (1966), who have made detailed studies of the composition of the cell wall of Mycobacterium tuberculosis BCG, considered that glycine was a mucopeptide constituent in the strain they examined because it was the only amino acid (other than alanine, glutamic acid and diaminopimelic acid) which was not removed by treatment with 'pronase'. In their strain, glycine was present in pronase-treated walls to the extent of 0.33 (diaminopimelic acid $=\mathrm{I} \cdot 0$ ). Similar studies on cell walls of $M$. phlei by Takeya, Hisatsume \& Inoue (1963) showed 'basal layer' (= mucopeptide) amino acids to be alanine, glutamic acid and diaminopimelic acid in ratio $1 \cdot 9: 1 \cdot 7: 1 \cdot 0$, with no other amino acid present in more than $20 \%$ of the amount of diaminopimelic acid. Both these groups of workers found arabinose and galactose to be the principal sugars present in the strains they examined.

The total amino acid content of the different fractions, also shown in Table 2, probably varies with a number of factors, the principal ones being the amounts of lipid and non-mucopeptide protein present. These latter factors might be expected to act in opposite directions, since a large amount of protein would raise the amino acid content and a large amount of lipid would make it relatively smaller; but in the absence of more definite information about the exact amounts of protein and lipid present the figures for total amino acid content are not very informative. However, the decrease from $25 \%$ amino acids in sample $\mathrm{C}$ to $\mathrm{I} 5 \%$ in sample D presumably represents a considerable removal of non-mucopeptide protein.

In previous work (Cummins, 1962) all strains of mycobacteria, corynebacteria and 
nocardias examined which had arabinose and galactose as characteristic cell-wall sugars showed cross agglutination when suspensions of their cell walls were tested against antisera to Mycobacterium smegmatis. From the results obtained with $M$. lepraemurium cell walls (Table 4) there seems to be no doubt that this antigen is present in them also.

It was somewhat unfortunate that the only Mycobacterium lepraemurium antiserum available appeared to contain very little antibody to the cell-wall antigens, but the results of cell-wall agglutination tests with $M$. smegmatis antiserum seemed quite conclusive of the presence in $M$. lepraemurium cell walls of the common mycobacterial antigen, since in the tests the titre at which $M$. lepraemurium cell walls reacted was at least as high as that for $M$. avium (Table 4). Moreover, the absorption test, using $M$. lepraemurium cell wall to absorb $M$. smegmatis antiserum, provides confirmatory evidence of the presence of the common antigen in the cell walls of $M$. lepraemurium.

One of use (C. S. C.) wishes to thank the Medical Research Council for grants for equipment and technical assistance.

\section{REFERENCES}

AtFIELD, G. N. \& MORRIS, C. J. O. R. (I96I). Analytical separations by high voltage paper electrophoresis. Amino acids in protein hydrolysates. Biochem. J. 81, 606.

BALfour-Jones, S. E. B. (1937). The experimental transmission of rat leprosy to the golden hamster (Cricetus auratus). J. Path. Bact. 45, 739.

Belknap, D. R., Camien, M. N. \& DUnN, M. S. (I96I). Amino acid composition of mycobacterial cell wall. Proc. Soc. exp. Biol. Med. ro7, 289.

Cummins, C. S. \& Harris, H. (I956). The chemical composition of the cell wall in some Grampositive bacteria and its possible value as a taxonomic character. J. gen. Microbiol. 14, 583.

Cummins, C. S. \& Harris, H. (1958). Studies on the cell wall composition and taxonomy of Actinomycetales and related groups. J. gen. Microbiol. $\mathbf{1 8 , ~} 173$.

Cummins, C. S. \& Slade, H. D. (I96I). Cell wall agglutination and precipitin tests on streptococci of different serological groups. Bact. Proc. (196I), p. 94.

Cummins, C. S. (1962). Chemical composition and antigenic structure of cell walls of Corynebacterium, Mycobacterium, Nocardia, Actinomyces and Arthrobacter. J. gen. Microbiol. 28, 35 .

HoARE, D. S. \& Work, E. (1957). The stereoisomers of $\alpha, \epsilon$-diaminopimelic acid. 2. Their distribution in the bacterial order Actinomycetales, and in certain Eubacteriales. Biochem. J. 65, 44I.

Jollès, P., SAMOUR, D. \& LeDERER, E. (1963). Isolement de fractions peptido-glycolipidique à partir des cires $\mathrm{D}$ de mycobactéries bovine, atypiques, aviaires et saprophytes. Biochim. biophys. Acta 78, 342.

Misaki, A., Yukawa, S., TsuchiYa, K. \& YamasaKi, T. (1966). Studies on cell walls of Mycobacteria I. Chemical and biological properties of the cell walls and mucopeptide of BCG. J. Biochem. 59, 388.

Rees, R. J. W., Valentine, R. C. \& Wong, P. C. (1960). Application of quantitative electron microscopy to the study of Mycobacterium lepraemurium and M. leprae. J. gen. Microbiol. 22, 443.

ReEs, R. J. W. \& GARbutT, E. W. (I962). Studies on Mycobacterium lepraemurium in tissue culture. I. Multiplication and growth characteristics in cultures of rat fibroblasts. Br. J. exp. Path. 43, 22 I.

Takeya, K., Hisatsume, K. \& Inoue, Y. (I963). Mycobacterial cell walls. II. Chemical composition of the basal layer. J. Bact. 85, 24 .

White, R. G., Coons, A. H. \& ConNolly, J. M. (1955). Studies on antibody production. IV. The role of a wax fraction of Mycobacterium tuberculosis in adjuvant emulsions on the production of antibody to egg albumin. J. exp. Med. ro2, 83 . 


\section{EXPLANATION OF PLATE}

Electron micrographs of Mycobacterium lepraemurium cell-wall fractions. (Pt shadowed.)

Fig. I. Sample C.

$\times 7,300$.

Fig. 2. Sample D, prepared from sample C by thorough extraction with lipid solvents (see text for details. 

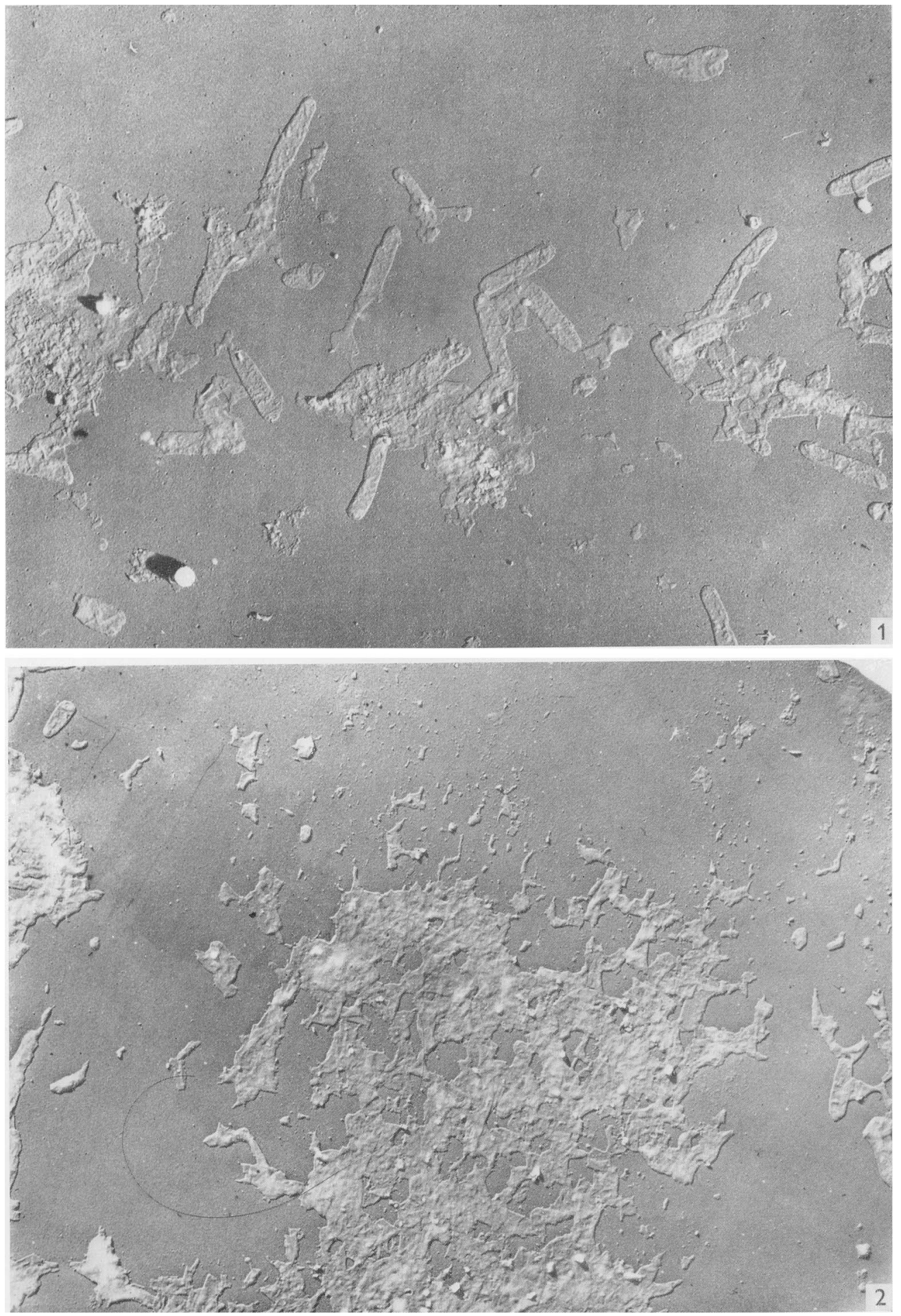